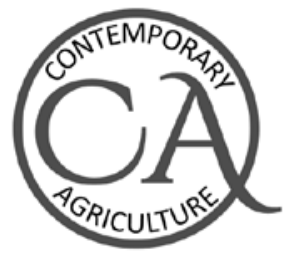

UDC: 628.1 .038

DOI: 10.1515/contagri-2016-0008

\title{
PHYSIOLOIGICAL AND MORPHOLOGICAL PARAMETRERS OF CULTIVATED PLANTS AS INDICATORS OF WATER QUALITY
}

\author{
Antonije ŽUNIĆ ${ }^{1}$, Slavica VUKOVIĆ ${ }^{1 *}$, Maria FATIMA DE ALPENDURADA ${ }^{2}$, \\ Sanja LAZIĆ ${ }^{1}$, Sonja GVOZDENAC ${ }^{1}$, Dragana ŠUNJKA ${ }^{1}$
}

Summary: By using biological assay in the laboratory were tested quality and impact of the water to the selected test plants: buckwheat (Fagopyrum esculentum) and cabbage (Brassica oleracea). Water was analyzed from two locations from the River Douro in Portugal. Physico-chemical analysis of general parameters in the water samples indicate that electrical conductivity and ammonium were detected in values exceeding MAC, according to Portuguese regulations on water quality. Also, in the analyzed samples of water in quantities that exceed the maximum allowable concentration values are: arsenic (As), selenium ( $\mathrm{Se}$ ), iron (Fe), magnesium (Mg). In tested samples several pharmaceuticals were detected. The obtained results indicate differences in tolerance of the test plants towards the quality of water. Physiological parameters (germination energy and germination) are not good indicators of water quality and more reliable can be considered some morphological traits (length, fresh and dry weight of root and shoot), that reacted in inhibition or stimulation, depending on water quality.

Key words: Douro, water, pollutants, phytoindicators, buckwheat, cabbage.

\section{INTRODUCTION}

Freshwater ecosystems are limited resources that are essential for agriculture, industry, existence and health of people. Nowadays, aquatic ecosystems around the world are increasingly threatened by various pollutants. Special attention has been given to the pollutants from agricultural production which significantly affect the quality of water, especially considering the effect of pesticides and fertilizers that end up dissolved in streams and underground water after improper and excessive application. In addition to agricultural production major pollutants of aquatic ecosystems are: industry, municipal wastewater, waterway traffic, accidents, etc. In order to ensure stable economic conditions in agriculture it is necessary to irrigate arid areas, but it is important to know whether the water used for irrigation meets certain quality and criteria. If such areas are irrigated with water that is contaminated it may cause adverse effects such as: decrease in yield and quality of crops, land degradation, pollution of surface waters and ground waters, harmful effects on humans and wildlife.

In order to prevent and reduce the pollution of aquatic ecosystems, it is necessary to carry out their continuous monitoring. By applying different physical, chemical and biological methods we can assess the degree of environmental pollution. Biological methods that involve the use of cultivated plants as test organisms, i.e. phytoindicators, are in use worldwide. Bioindicators are organisms that are used to detect changes in the

\footnotetext{
${ }^{1}$ Antonije Žunić, MSc, PhD student, Slavica Vuković, PhD assistant professor, Sanja Lazić, PhD full professor, Dragana Šunjka, PhD assistant professor, Sonja Gvozdenac, MSc, research assistant, University of Novi Sad, Faculty of Agriculture, Trg D. Obradovića 8, Novi Sad;

${ }^{2}$ Maria Fatima full professor de Alpendurada, PhD Water Institue of the Northern Region, Porto, Portugal

*Corresponding author: Slavica Vuković, e-mail: vukovic@polj.uns.ac.rs , Phone: +381214853333.
} 
environment and demonstrate the presence of pollutants and their impact on the ecosystem. For agricultural production biological tests that are used for evaluation of water quality are of great importance. The results of bioassays directly indicate water suitability for irrigation and cultivation of plants.

\section{MATERIAL AND METHODS}

Water sampling was conducted in 2014. by experts from "Northern Region Water Institute"- IAREN (Instituto da Água da Região do Norte) from Portugal. Water was sampled from two sites along the River Douro in Portugal.

The sampling sites and coordinates:

• Douro I- Rio Douro (Ribeira) ～(N 41 8'25.77 "W 8 36'41.86")

• Douro II- Rio Douro (Águas do Douro e Paiva) (N $41^{\circ}$ 4'23.20 "W 8 28'51.92")

Physico-chemical analysis of water was also conducted in Portugal and includes the following parameters: general parameters of water quality, organic compounds, heavy metals, pesticides, pharmaceuticals. For chemical analysis, depending on the expected pollutants, the following techniques were used: Atomic Adsorption Spectrometry-Flame Technique (EPA Method 7000B), Liquid Chromatography-Tandem Mass Spectrometry (LCMS-MS), Gas Chromatography Mass Spectrometry (GC-MS) and Inductively Coupled plasma Mass spectrometry (ICP-MS). For the extraction that preceded detection of the presence of pollutants Solid Phase Extraction (SPE) and Accelerated Solvent Extraction (ASE) were used. The maximum allowable quantities (MAC) used in this experiment are stipulated by Portuguese regulations Decreto-Lei $n^{\circ}$ 103/2010, Decreto-Lei $n^{\circ}$ 236/1998 and the European Directive 2008/105/EC.

Test plants were cabbage (Brassica oleracea L.) and buckwheat (Fagopyrum esculentum Moench.). Water quality was evaluated using physiological (germination energy and germination $/ \% /$ ) and morphological parameters (length of roots and shoots of seedlings $/ \mathrm{cm} /$, fresh and dry weight of roots and shoots of seedlings $/ \mathrm{g} /$ ) of the test plants.

A filter-paper method by ISTA (International rules for seed testing) for 2013 and the Regulations of the seeds quality for agricultural plants („Sl. List SFRJ“, no. 47/87, 60/87, 55/88 and 81/89 and „Sl. List SRJ“, no. 16/92, 8/93, 21/93, 30/94, 43/96, 10/98, 15/2001 and 58/2002, „Sl. List RS“, no. 23/2009, 64/2010, 72/2010 and 34/2013) was used. The plastic box containers $(21 \times 15 \times 5 \mathrm{~cm})$ are filled with two layers of cotton wool paper at the bottom, over which goes filter paper folded in the form of an accordion. Paper was soaked with $25 \mathrm{ml}$ of sampled water or with distilled water as control variant. Then, after each repetition 50 grains of buckwheat are placed in plastic boxes or 100 seeds of cabbage in Petri dishes (in the same manner and with the same quantity of sample water). The containers were stored in a thermostat at a temperature of $25 \pm 2^{\circ} \mathrm{C}$, in the dark. The experiment was set in four replications. Buckwheat seed germination was determined after 7 and for cabbage after 10 days. Germination energy and germination are assessed by counting the germinated seeds, un-germinated and atypical seedlings compared to the total number and expressed in percentages.

In order to assess the morphological parameters, from each repetition were selected 25 plants and placed on the three-layer paper strips dimensions $14 \times 60 \mathrm{~cm}$. The strips are pre-moistened with $30 \mathrm{ml}$ of test water, then wrapped in rolls, placed in plastic bags and then stored in a thermostat. After 7 days (buckwheat) and 10 days (cabbage), the length of root and shoot from the rolls were measured. Fresh root and shoot weight was measured on an analytical, digital balance. When the measurement of fresh weight is done, metal containers with samples were placed in the oven at $60^{\circ} \mathrm{C}$ for $24 \mathrm{~h}$ and 1 hour at $130^{\circ} \mathrm{C}$, and finally dry weight of root and shoot was measured.

Results for germination energy and germination are expressed in percentages. The values of morphological parameters are shown as average values and are processed using the Analysis of Variance and Duncan's multiple comparison test, with confidence interval of $95 \%$, in the statistical software R ver. 3.2.2.

\section{RESULTS}

According to the results of physico-chemical analysis, in water sample Douro I electrical conductivity exceeded maximum allowed values by $7.5 \mathrm{x}$ and ammonium (14x). Sample Douro I excess limit values for conductivity, so this water does not meet the required quality for irrigation.

Exceeding level of ammonium (1.2x) was also detected in the sample Douro II, however, water from this sample is a less polluted than the Douro I. 
Table 1. Physico-chemical analysis of the general parameters in analyzed water samples

\begin{tabular}{|c|c|c|c|c|c|c|c|c|}
\hline \multirow[b]{2}{*}{ Location } & \multicolumn{8}{|c|}{ Detected values of general parameters } \\
\hline & pH & $\begin{array}{c}\mathrm{EC} \\
(\mathrm{mS} / \mathrm{cm}) \text { at } \\
20^{\circ} \mathrm{C}\end{array}$ & $\mathbf{t}^{\circ} \mathrm{C}$ & $\begin{array}{l}\mathrm{NO}_{3}^{-} \\
\mathrm{mgN} / \mathrm{l}\end{array}$ & $\begin{array}{l}\mathrm{NO}_{2}^{-} \\
\mathrm{mgN} / \mathrm{l}\end{array}$ & $\begin{array}{c}\mathrm{NH}_{3} \\
\mathrm{mgN} / \mathrm{l}\end{array}$ & $\begin{array}{c}\mathbf{P} \\
\mathrm{mgP} / \mathbf{l}\end{array}$ & $\begin{array}{c}\mathrm{B} \\
\mathrm{mgB} / \mathrm{l}\end{array}$ \\
\hline Douro I & 7.6 & 7450 & 18.1 & 4.8 & $<0.1$ & 0.7 & 0.12 & 0.5 \\
\hline Douro II & 7.6 & 240 & 17.5 & 4.6 & $<0.1$ & 0.06 & 0.03 & $<0.1$ \\
\hline MAC & $5-9$ & $\leq 1000$ & 30.0 & 10.0 & 1.0 & 0.05 & 1.0 & 1.0 \\
\hline
\end{tabular}

The results of chemical analysis on the contents of heavy metals and other parameters from the list of priority pollutants, indicates to an extremely high amount of selenium (Se), arsenic (As) and magnesium (Mg) in the water from the sample Douro I, in quantities that exceed MAC according to the mentioned regulations. Also high amounts of the iron (Fe) are found in a water sample Douro II.

Table 2. The content of heavy metals and other elements from the list of priority water pollutants in the analyzed samples

\begin{tabular}{|c|c|c|c|c|c|c|c|c|c|c|}
\hline \multirow[b]{2}{*}{ Location } & \multicolumn{10}{|c|}{ Detected values of heavy metals and other elements } \\
\hline & $\begin{array}{c}\text { Cd } \\
(\mu g / l)\end{array}$ & $\begin{array}{c}\text { Se } \\
(\mu g / l)\end{array}$ & $\begin{array}{c}\text { As } \\
(\mu \mathrm{g} / \mathrm{l})\end{array}$ & $\begin{array}{c}\text { Mo } \\
(\mu \mathrm{gg} / \mathrm{l})\end{array}$ & $\begin{array}{c}\mathrm{Cr} \\
(\mu \mathrm{g} / \mathrm{l})\end{array}$ & $\begin{array}{c}\mathrm{Pb} \\
(\mu \mathrm{g} / \mathrm{l})\end{array}$ & $\begin{array}{c}\mathrm{Mn} \\
(\mathrm{pg} / \mathrm{l})\end{array}$ & $\begin{array}{c}\mathrm{Fe} \\
(\mu \mathrm{g} / \mathrm{l})\end{array}$ & $\underset{(\mu g / l)}{Z n}$ & $\underset{(\mathbf{m g} / \mathbf{l})}{\mathbf{M g}}$ \\
\hline Douro I & $<0$ & 47 & 15 & $<<0$ & 5 & $<0$ & 11 & 95 & $<1$ & 210 \\
\hline Douro II & $<0$ & $<2$ & 2. & $<0$ & 5 & $<0$ & 17 & 17 & $<1$ & 6.2 \\
\hline MAC & 5 & 10 & 10 & 50 & 50 & 50 & 10 & 10 & 50 & 50 \\
\hline
\end{tabular}

Pesticide substances were below the limit of detection in all tested water samples.

Table 3. The content of pesticides and organic compounds in water samples

\begin{tabular}{|l|c|r|r|r|r|r|r|}
\hline \multirow{3}{*}{ Location } & \multicolumn{7}{|c|}{ Parameters ( $\mu \mathrm{g} / \mathbf{l})$} \\
\cline { 2 - 8 } & Endosulfan & MCPA & Alachlor & Simazin & Fonofos & Aldrin & Benzene \\
\hline Douro I & $<0.009$ & $<0.0$ & $<0.01$ & $<0.05$ & $<0.01$ & $<0.01$ & $<0.28$ \\
\hline Douro II & $<0.009$ & $<0.0$ & $<0.01$ & $<0.05$ & $<0.01$ & $<0.01$ & $<0.28$ \\
\hline MAC & $\mathbf{0 . 0 1}$ & $\mathbf{0 . 5}$ & $\mathbf{0 . 7}$ & $\mathbf{4 . 0}$ & $\mathbf{1 0 . 0}$ & $\mathbf{3 0 . 0}$ & $\mathbf{5 0 . 0}$ \\
\hline
\end{tabular}

Chemical analysis of pharmaceutical contents, in water sample Douro I, showed that the following pharmaceuticals were registered over the limit of detection: paracetamol, naproxen, ibuprofen, hydrochlorothiazide and azithromycin. The test parameters of sample Douro II were below the limit of detection.

Table 4. The content of detected of pharmaceuticals in water samples

\begin{tabular}{|l|c|c|c|c|c|}
\hline \multirow{3}{*}{ Location } & \multicolumn{5}{|c|}{ Parameters (ng /) } \\
\cline { 2 - 6 } & Paracetamol & Naproxen & Ibuprofen & Hydrochlorothiazide & Azithromycin \\
\hline Douro I & $\mathbf{9 8 . 0}$ & $\mathbf{7 0 . 0}$ & $\mathbf{1 2 0 . 0}$ & $\mathbf{5 0 . 0}$ & $\mathbf{2 5 . 0}$ \\
\hline Douro II & $<0.02$ & $<0.04$ & $<0.17$ & $<0.03$ & $<0.01$ \\
\hline
\end{tabular}

Bioassay results - test plant buckwheat

Germination energy and germination. Buckwheat seeds were not influenced by the quality of the water and all values are on the same level of significance with each other and with the control $(\mathrm{F}=0.17 \mathrm{~ns}, \mathrm{p}>0.05 ; \mathrm{F}=0.23 \mathrm{~ns}, \mathrm{p}$ $>0.05)$. 
Table 5. Water quality influence on physiological parameters

\begin{tabular}{|c|c|c|}
\hline Parameters & Water sample & Values (\%) \\
\hline \multirow{4}{*}{ Germination energy (\%) } & Douro I & $95.75 \pm 0.96^{\mathrm{a}}$ \\
\hline & Douro II & $96.25 \pm 1.26^{\mathrm{a}}$ \\
\hline & Control & $96.00 \pm 1.41^{\mathrm{a}}$ \\
\hline & F value & $0.17 \mathrm{~ns}$ \\
\hline \multirow{4}{*}{ Germination (\%) } & Douro I & $97.25 \pm 0.96^{\mathrm{a}}$ \\
\hline & Douro II & $97.50 \pm 1.00^{\mathrm{a}}$ \\
\hline & Control & $97.00 \pm 1.15^{\mathrm{a}}$ \\
\hline & F value & $0.23 \mathrm{~ns}$ \\
\hline
\end{tabular}

*a,b,c- letter codes used to illustrate groupings. Any two means with the same single-letter code cannot be said to be significantly different.

Length of Root. Length of root has not been influenced by the quality of the water and all values are on the same level of significance with each other and with the control $(\mathrm{F}=0.91 \mathrm{~ns}, \mathrm{p}>0.05)$.

Fresh weight of root. Fresh weight of root has not been influenced by the quality of the water and all values are on the same level of significance with each other and with the control ( $F=1.56 \mathrm{~ns}, \mathrm{p}>0.05)$.

Dry weight of root. Root dry weight was stimulated in the sample Douro I (by 33\% compared to control), while the water from sample Douro II did not significantly affect dry weight of buckwheat root. Differences between treatments were statistically significant $\left(\mathrm{F}=15.67^{*}, \mathrm{p}<0.05\right)$.

Length of shoot. Buckwheat was significantly stimulated in Douro II sample (by $43 \%$ compared to control), while the water from sample Douro I did not significantly affect shoot length of buckwheat. Differences between treatments were statistically significant $\left(\mathrm{F}=11.14^{*}, \mathrm{p}<0.05\right)$.

Fresh weight of shoot. The highest average value of fresh weight was recorded in the sample Douro II (30\% higher, compared to the control), while the water from sample Douro II did not significantly affect shoot fresh weight of buckwheat. Differences between treatments were statistically significant ( $F=29.30 *, p<0.05$ ).

Dry weight of shoot. This parameters of buckwheat shoots was not affected by water quality and all values are on the same level of significance. ( $F=0.47 \mathrm{~ns}, \mathrm{p}>0.05$ ).

Table 6. Impact of water quality on morphological parameters

\begin{tabular}{|c|c|c|c|}
\hline Parameters & Water sample & Values & $\%$ \\
\hline \multirow{4}{*}{$\begin{array}{l}\text { Length of root } \\
\qquad(\mathrm{cm})\end{array}$} & Douro I & $5.62 \pm 2.24^{\mathrm{a}}$ & 96 \\
\hline & Douro II & $6.95 \pm 0.78^{\mathrm{a}}$ & 118 \\
\hline & Control & $5.87 \pm 0.96^{\mathrm{a}}$ & 100 \\
\hline & F value & \multicolumn{2}{|c|}{$\begin{array}{r}0.91 \mathrm{~ns} \\
\end{array}$} \\
\hline \multirow{4}{*}{$\begin{array}{l}\text { Fresh weight of } \\
\quad \operatorname{root}(\mathrm{g})\end{array}$} & Douro I & $0.32 \pm 0.12^{\mathrm{a}}$ & 148 \\
\hline & Douro II & $0.31 \pm 0.08^{\mathrm{a}}$ & 145 \\
\hline & Control & $0.22 \pm 0.08^{\mathrm{a}}$ & 100 \\
\hline & F value & \multicolumn{2}{|c|}{$1.56 \mathrm{~ns}$} \\
\hline \multirow{4}{*}{$\begin{array}{l}\text { Dry weight of root } \\
\text { (g) }\end{array}$} & Douro I & $0.04 \pm 0.004^{\mathrm{a}}$ & 133 \\
\hline & Douro II & $0.02 \pm 0.004^{b}$ & 79 \\
\hline & Control & $0.03 \pm 0.005^{b}$ & 100 \\
\hline & F value & \multicolumn{2}{|c|}{$15.67 *$} \\
\hline \multirow{4}{*}{$\begin{array}{l}\text { Length of shoot } \\
\quad(\mathrm{cm})\end{array}$} & Douro I & $4.90 \pm 1.13^{b}$ & 101 \\
\hline & Douro II & $6.97 \pm 0.50^{\mathrm{a}}$ & 143 \\
\hline & Control & $4.87 \pm 0.17^{b}$ & 100 \\
\hline & F value & \multicolumn{2}{|c|}{$11.14 *$} \\
\hline \multirow{4}{*}{$\begin{array}{l}\text { Fresh weight of } \\
\text { shoot (g) }\end{array}$} & Douro I & $2.02 \pm 0.24^{b}$ & 94 \\
\hline & Douro II & $2.80 \pm 0.04^{\mathrm{a}}$ & 130 \\
\hline & Control & $2.14 \pm 0.11^{b}$ & 100 \\
\hline & F value & \multicolumn{2}{|c|}{$29.30 *$} \\
\hline
\end{tabular}




\section{Extension of table 6.}

\begin{tabular}{|l|l|l|c|}
\hline \multirow{3}{*}{$\begin{array}{c}\text { Dry weight of } \\
\text { shoot (g) }\end{array}$} & Douro I & $0.24 \pm 0.027^{\mathrm{a}}$ & 100 \\
\cline { 2 - 4 } & Douro II & $0.23 \pm 0.028^{\mathrm{a}}$ & 95 \\
\cline { 2 - 4 } & Control & $0.24 \pm 0.024^{\mathrm{a}}$ & 100 \\
\cline { 2 - 4 } & F value & \multicolumn{2}{|c|}{$\mathbf{0 . 4 7} \mathbf{~ n s}$} \\
\hline
\end{tabular}

*a,b,c- letter codes used to illustrate groupings. Any two means with the same single-letter code cannot be said to be significantly different.

The achieved results indicate that the physiological parameters (germination energy and germination) in the case of buckwheat are not good indicators of water quality, and more reliable may be considered some morphological parameters (dry weight of root, length and fresh weight of shoot).

\section{Bioassay results - test plant cabbage}

Germination energy and germination. Water from the sample Douro I significantly reduced the germination energy and germination of cabbage compared to the control, even though values were above the minimum germination stipulated by the regulation $(>88 \%)(F=8.29 *$, $p<0.05 ; F=7.59 *, p<0.05)$.

Table 7. Water quality influence on physiological parameters

\begin{tabular}{|c|l|c|}
\hline Parameters & Water sample & Values (\%) \\
\hline \multirow{3}{*}{$\begin{array}{c}\text { Germination } \\
\text { energy (\%) }\end{array}$} & Douro I & $91.25 \pm 2.22^{\mathrm{b}}$ \\
\cline { 2 - 3 } & Douro II & $94.75 \pm 1.26^{\mathrm{a}}$ \\
\cline { 2 - 3 } & Control & $95.75 \pm 1.26^{\mathrm{a}}$ \\
\cline { 2 - 3 } & \multicolumn{1}{|c|}{ F value } & $\mathbf{8 . 2 9}$ \\
\hline \multirow{4}{*}{ Germination (\%) } & Douro I & $93.25 \pm 0.96^{\mathrm{b}}$ \\
\cline { 2 - 3 } & Douro II & $95.75 \pm 1.50^{\mathrm{a}}$ \\
\cline { 2 - 3 } & Control & $96.25 \pm 0.96^{\mathrm{a}}$ \\
\cline { 2 - 3 } & $\mathbf{7 . 5 9}$ \\
\hline
\end{tabular}

*a,b,c- letter codes used to illustrate groupings. Any two means with the same single-letter code cannot be said to be significantly different.

Length of Root. Length of root has not been influenced by the quality of the water and all values are on the same level of significance with each other and with the control $(\mathrm{F}=0.55 \mathrm{~ns}, \mathrm{p}>0.05)$.

Fresh weight of root. Fresh weight of root has not been influenced by the quality of the water and all values are on the same level of significance with each other and with the control $(F=2.16 n s, p>0.05)$.

Dry weight of root. The highest dry weight of root, compared with the control was registered in the water from sample Douro II (increased by 11\%), while in the treatment with water from sample Douro I was significantly reduced by $15 \%$. Significant differences were observed between treatments $\left(F=6.13^{*}, \mathrm{p}<0.05\right)$.

Length of shoot. Length of shoot has been highly significantly stimulated by the water from Douro I (by 39\%) as compared to control, and from Douro II by $16 \%$. Differences between treatments were statistically highly significant $\left(\mathrm{F}=22.25^{* *}, \mathrm{p}<0.01\right)$.

Fresh weight of shoot. Fresh weight of shoot has not been influenced by the quality of the water and all values are on the same level of significance with each other and with the control $(\mathrm{F}=0.24 \mathrm{~ns}, \mathrm{p}>0.05)$.

Dry weight of shoot. Dry weight of shoots was not under the influence of water quality and all values are on the same level of significance with the control. ( $F=0.72 n s, p>0.05)$.

Table 8. Impact of water quality on morphological parameters

\begin{tabular}{|c|l|c|c|}
\hline Parameters & Water sample & Values & \% \\
\hline \multirow{3}{*}{ Length of root (cm) } & Douro I & $3.70 \pm 0.64^{\mathrm{a}}$ & 97 \\
\cline { 2 - 4 } & Douro II & $4.07 \pm 0.36^{\mathrm{a}}$ & 107 \\
\cline { 2 - 4 } & Control & $3.80 \pm 0.53^{\mathrm{a}}$ & 100 \\
\cline { 2 - 4 } & \multicolumn{2}{|c|}{$\mathbf{0 . 5 5} \mathbf{~ n s}$} \\
\hline Extension of table 8.
\end{tabular}




\begin{tabular}{|c|c|c|c|}
\hline \multirow{4}{*}{$\begin{array}{l}\text { Fresh weight of } \\
\text { root (g) }\end{array}$} & Douro I & $0.04 \pm 0.03^{\mathrm{a}}$ & 83 \\
\hline & Douro II & $0.10 \pm 0.04^{\mathrm{a}}$ & 167 \\
\hline & Control & $0.06 \pm 0.03^{\mathrm{a}}$ & 100 \\
\hline & F value & \multicolumn{2}{|c|}{$2.16 \mathrm{~ns}$} \\
\hline \multirow{4}{*}{$\begin{array}{l}\text { Dry weight of root } \\
\text { (g) }\end{array}$} & Douro I & $0.007 \pm 0.001^{b}$ & 85 \\
\hline & Douro II & $0.010 \pm 0.001^{\mathrm{a}}$ & 111 \\
\hline & Control & $0.009 \pm 0.001^{\mathrm{ab}}$ & 100 \\
\hline & F value & \multicolumn{2}{|c|}{$6.13 *$} \\
\hline \multirow{4}{*}{$\begin{array}{l}\text { Length of shoot } \\
\text { (cm) }\end{array}$} & Douro I & $6.90 \pm 0.57^{\mathrm{a}}$ & 139 \\
\hline & Douro II & $5.75 \pm 0.26^{b}$ & 116 \\
\hline & Control & $4.97 \pm 0.33^{\mathrm{c}}$ & 100 \\
\hline & F value & \multicolumn{2}{|c|}{$22.25 * *$} \\
\hline \multirow{4}{*}{$\begin{array}{l}\text { Fresh weight of } \\
\text { shoot (g) }\end{array}$} & Douro I & $0.79 \pm 0.60^{\mathrm{a}}$ & 103 \\
\hline & Douro II & $0.91 \pm 0.11^{\mathrm{a}}$ & 119 \\
\hline & Control & $0.77 \pm 0.10^{\mathrm{a}}$ & 100 \\
\hline & F value & \multicolumn{2}{|c|}{$0.24 \mathrm{~ns}$} \\
\hline \multirow{4}{*}{$\begin{array}{l}\text { Dry weight of shoot } \\
\text { (g) }\end{array}$} & Douro I & $0.054 \pm 0.005^{\mathrm{a}}$ & 113 \\
\hline & Douro II & $0.051 \pm 0.012^{\mathrm{a}}$ & 109 \\
\hline & Control & $0.048 \pm 0.004^{\mathrm{a}}$ & 100 \\
\hline & F value & \multicolumn{2}{|c|}{$0.72 \mathrm{~ns}$} \\
\hline
\end{tabular}

*a,b,c- letter codes used to illustrate groupings. Any two means with the same single-letter code cannot be said to be significantly different.

Actual test results indicate that physiological parameters (germination energy and germination), in the case of cabbage are not reliable indicators of water quality, while morphological parameters were better indicators of degraded water quality (dry weight of root and length of shoot).

\section{DISCUSSION}

Bioassay test results indicate the different sensitivity of tested plant species and parameters as well as their validity in assessing water contamination.

The results of physico-chemical analysis indicate to an increased value for electrical conductivity and ammonium cocncentration in tested water samples.

Electrical conductivity, concentration of salt in the water, is an essential characteristic of water for irrigation and it significantly affects the crops productivity. The primary effect of high salt concentration is reflected in the inability of the plant to up-take water from the soil solution which leads to a physiological drought. The higher the conductivity, the less water is available to plants (Bauder et al., 2014).

The results of chemical analysis on the contents of heavy metals and other parameters from the list of priority pollutants, indicates to an extremely high amount of selenium, arsenic, magnesium and iron .

Heavy metals are very harmful because of their non-biodegradable nature, long biological half-lives and their potential to accumulate in different body parts. Most of the heavy metals are extremely toxic because of their solubility in water (Arora et. al., 2008).

Arsenic has a long history of use as a homicidal agent, but in the past 100 years arsenic, has been used as a pesticide, a chemotherapeutic agent and a constituent of consumer products. In some areas of the world, high levels of arsenic are naturally present in drinking water and are a toxicological concern (Hughes et al., 2011). Today As is no longer in use, but it is necessary to determine its residual effect. In the absence of material that firmly adsorbs As in the soil, causes the leaching of arsenic into the deeper soil layers, and even in the ground-waters, which is even more dangerous (Ubavić and Bogdanović, 2001). Arsenic is non-essential and generally toxic to plants. Roots are usually the first tissue to be exposed to As, where the metalloid inhibits root extension and proliferation. At sufficiently high concentrations, As interferes with critical metabolic processes, which can lead to death (Finnegan and Weihua, 2012).

Selenium has not yet been classified as an essential element for plants, although its role has been considered to be beneficial for plants that are capable of accumulating large amounts of the element (Shanker, 2006). According to the research conducted by Hartikainen et. al. (2000), high concentrations of selenium in plants lead to harmful effects, which are reflected in the reduction of biomass and inhibition of seed germination. 
Magnesium is an essential nutrient for plants and animals (Wlikinson et. al., 1990). Even though is essential, excess $\mathrm{Mg}^{2}$ amounts in the plant might inhibit photosynthesis and plant growth, particularly during dehydration (Shaul, 2002).

Iron is one of 16 essential elements for plant growth and reproduction. Although required by plants in small amounts, Fe is involved in many important compounds and physiological processes in plants. Iron is involved in the manufacturing process of chlorophyll, and it is required for certain enzyme functions. Deficiency symptoms generally consist of a yellowing or chlorosis of the youngest leaves. Toxicity of iron has not been reported under most aerobic plant production systems (Hochmuth, 2011).

Increased amounts of arsenic, selenium and magnesium from the water sample Douro I caused stimulation of dry weight of buckwheat root, and shoot length of cabbage, so these results are not in accordance with the previously presented claims. But, cabbage germination energy, germination and dry weight of root were notably inhibited by same water, and these results back up mentioned claims for the excess amounts of As, Se and Mg.

Pesticide substances were below the limit of detection in all tested water samples, but chemical analysis of pharmaceutical contents showed that the following pharmaceuticals were registered over the limit of detection: paracetamol, naproxen, ibuprofen, hydrochlorothiazide and azithromycin.

In recent years, the occurrence and fate of pharmaceutically active compounds (PhACs) in the aquatic environment has been recognized as one of the emerging issues in environmental chemistry (Heberer, 2002). The main sources of pollution of surface and ground-waters with these compounds are urban and agricultural waste waters or households, hospitals and agricultural lands (Robinson et al., 2007). Also, the significant sources of drugs in the environment are wastewaters from the pharmaceutical industry and the farms, on which they are used extensively for livestock and poultry treatments (Grujic, 2009). On most farms antibiotics are used to treat the infections, as prevention and a food additive for animal faster growth (Hirsch et al. 1999).

\section{CONCLUSIONS}

Based on the conducted tests and the results achieved on the influence of water quality (Douro I, Douro II) on the test plants (buckwheat, cabbage) it can be concluded that:

- In the water sample from the Douro river site I, in the pollutants detected in the quantities exceeding MAC according to the Regulations, were: arsenic (As) and selenium (Se), while ammonium and electrical conductivity were also above the limit values. The pharmaceuticals (hydrochlorothiazide, acetaminophen, naproxen, and ibuprofen azithromycin) were also detected. Based on the biological test of water quality on phytoindicators, plants reacted in a significant stimulation of the dry weight of root (buckwheat) and length of shoot (cabbage), which can be attributed to the presence of selenium and ammonium. In contrast, seed germination of cabbage and dry weight of root seedlings of cabbage were significantly inhibited by water sample Douro I, which can be correlated with the increased content of As.

- In a sample of water from the site Douro II in quantities exceeding MAC, iron (Fe) and ammonium were registered, and none of the tested pharmaceuticals. Water significantly stimulated length and fresh weight of shoots of buckwheat and the shoot length of cabbage. These effects are attributed to the presence of iron in a greater amount in this sample.

Bioassay test results indicate the different sensitivity of tested plant species and parameters as well as their validity in assessing water contamination. Different plant species and parameters responded variously to the quality of the water sampled. An expressed variability of parameters indicates their potential as possible bioindicators.

\section{ACKNOWLEDGMENT}

The research was conducted within the project III 43005, funded by the Ministry of Education and Science of the Republic of Serbia.

The research was carried out in the course of project of Bilateral cooperation between the Republic of Serbia and the Republic of Portugal (2012-2014).

\section{REFERENCES}

ARORA, M., KIRAN, B., RANI, S., RANI, A., KAUR, B., MITTALL, N. (2008): Heavy metal accumulation in vegetables irrigated with water from different sources. Food Chemistry Journal, 111, 811-815.

BAUDER, T.A., WASKOM, R.M.,SUTHERLAND, P.L and DAVIS, J.G. (2014): Irrigation Water Quality Criteria. Colorado State University, 1-5. 
FINNEGAN, P. , WEIHUA, C. (2012): Arsenic Toxicity: The Effects on Plant Metabolism, Journal List, Front Physiol, v.3, 2012., 2-5.

GRUJIĆ, S. (2009): Određivanje tragova lekova u vodi metodom tečne hromatografije sa tandem masenom spektrometrijom. Tehnološko-metalurški fakultet, Univerzitet u Beogradu, 2009, 4-10.

HARTIKAINEN, H., XUE, T., PIIRONEN, V. (2000): Selenium as an antioxidant and pro-oxidant in ryegrass. Plant and Soil, 225, 193-20.

HEBERER, T. (2002): Occurrence, fate, and removal of pharmaceutical residues in the aquatic environment: a review of recent research data, Toxicol. Lett., 131, 5-17.

HIRSCH, R., TERNES, T., HABERER, K. and KRATZ, K-L. (1999): Occurrence of antibiotics in the aquatic environment, Sci. Total Environ., 225, 109-118.

HOCHMUTH, G. (2011): Iron (Fe) Nutrition of Plants. University of Florida, IFAS Exstension, 1-7.

HUGHES, F. M., BECK, D. B., CHEN, Y., LEWIS A. S. and THOMAS J. D. (2011): Arsenic Exposure and Toxicology: A Historical Perspective. Oxford Journals, Volume 123, Issue 2, 305-332.

ROBINSON, I., JUNQUA, G., VAN COILLIE, R. and THOMAS, O. (2007): Trends in the detection of pharmaceutical products, and their impact and mitigation in water and wastewater in North America, Anal. Bioanal. Chem., 387, 1143-1151.

SHANKER, A. K. (2006): Countering UV-B stress in plants: does selenium have a role? Plant and Soil 282, 2126.

SHAUL, O. (2002): Magnesium transport and function in plants: the tip of the iceberg. Kluwer Academic Publishers, BioMetals 15: 309-323.

UBAVIĆ, M., BOGDANOVIĆ, D. (2001): Agrohemija. Novi Sad, 2001., 138-155.

WILKINSON, S., R., WELCH, R.,M., MAYLAND, H., F., GRUNES, D., L. (1990): Magnesium in Plants: Uptake, Distribution, Function and Utilization by Man and Animals. Metal ions in Biological Systems, vol. 26., 3352. 


\title{
FIZIOLOŠKI I MORFOLOŠKI PARAMETRI GAJENIH BILJAKA KAO POKAZATELJI KVALITETA VODE
}

\author{
Antonije ŽUNIĆ, Slavica VUKOVIĆ, Maria FATIMA DE ALPENDURADA, Sanja LAZIĆ, \\ Sonja GVOZDENAC, DRAGANA ŠUNJKA
}

Izvod: Primenom biološkog testa u laboratoriji je ispitan kvalitet vode, kao i uticaj polutanata na test biljke: heljda (Fagopirum esculentum) i kupus (Brassica oleracea). Voda potiče sa dva lokaliteta iz reke Douro u Portugalu. Fizičko-hemijska analiza opštih parametara u uzorcima ispitanih voda ukazuju na to da su elektroprovodljivost i amonijak iznad graničnih vrednosti, prema važećim portugalskim propisima i zakonima o kvalitetu vode. Isto tako, u analiziranim uzorcima vode su detektovani arsen (As), selen (Se), gvožđe (Fe) i magnezijum $(\mathrm{Mg})$ u količinama koje premašuju maksimalno dozvoljene koncentracije. Preko granice detekcije u nekim uzorcima su registrovani neki medicinski proizvodi i lekovi. Dobijeni rezultati ukazuju na razlike u toleranciji testiranih biljaka prema polutantima koji su detektovani u vodi. Fiziološki parametri (energija klijanja i klijavost) nisu se pokazali kao dobri pokazatelji kvaliteta vode, dok se pouzdanijim mogu smatrati neki morfološke parametri (dužina izdanka, sveža i suva masa korena i izdanaka), koji su reagovali inhibicijom ili stimulacijom, u zavisnosti od kvaliteta vode.

Ključne reči: Douro, voda, zagađivači, fitoindikatori, heljda, kupus.

Received / Primljen: 13.04.2016.

Accepted / Prihvaćen: 20.07.2016. 